\title{
An Argument for Investigation into Collaborative, Choreomusical Relationships within Contemporary Performance: A Practical and Theoretical Enquiry into the Distinct Contributions of a Collaborative, Co-creative Approach
}

\author{
Jess Rymer \\ School of Performing Arts, \\ University of Malta \\ jessrymer@gmail.com
}

Received 7 May 2017; accepted 26 September 2017; published 21 November 2017.

\begin{abstract}
This paper argues that for both creators of a choreomusical work, a collaborative creative process must be worthwhile, enjoyable, or contribute something unique to motivate artists to collaborate at a time where, to some degree, technology negates the necessity to do so. Therefore, the scholar interested in choreomusical relationships should also be interested in collaborative, creative methods.

The research considers cross-disciplinary and inter-disciplinary working processes in music and dance in the twentieth and twenty-first centuries to enquire into the ways that choreomusical relationships have developed for composers and choreographers working collaboratively. It asks whether there are factors which should be considered in a collaborative working method between composer and choreographer to achieve a co-creative endeavor which is satisfactory for both parties. Satisfactory, co-creative results are defined by the satisfaction of both collaborators throughout the creative process, regardless of the end result.

These questions were addressed both through historical analysis of collaborations within contemporary dance, and exploration of how choreomusical collaboration can be successful or unsuccessful in terms of co-creation and the satisfaction of each party within current artistic practice. Informed practical research and the use of journals coincide with a grounded theory approach: through analysis of both sets of data, factors which help and hinder choreomusical collaboration in terms of
\end{abstract}


co-creative approaches were identified. The results of this analysis are presented in a spectrum model of possible working relationships between composer and choreographer; this paper applies this to case studies identified within the research in terms of cognitive innovation.

Keywords: choreography; choreomusical; collaboration; music.

\section{Introduction}

The level of co-authorship, satisfaction or enjoyment of a creative working method does not always reveal itself in the result of collaboration; perceived choreomusical confluence can be achieved through a detached process as demonstrated by working methods of much classical ballet.

Research concerning music and dance largely focuses on choreomusical relationships and audience perception of the performance, an example being one of the most significant choreomusical texts in modern dance: Paul Hodgins' Relationships Between Score and Choreography in Twentieth-Century Dance Music, Movement and Metaphor (1992). In this text Hodgins actually refers to the nature of collaboration as ineffable; the collaborative process is recognized as being distinct from the environment and perceptions of the piece (p. 9). Research considering cognitive innovation in other disciplines contradicts this, suggesting a process evolves in relational terms with its surroundings and intended audience (Glăveanu, 2014, p. 27).

This lack of research and the importance of this area in the development in choreomusical study is mentioned in several recent choreomusical articles. McMains and Thomas (2013) stress the importance of collaboration when discussing choreomusical relationships:

Just as great music or dance is produced through informed manipulation of tension and release, meaningful music-dance relationships are created through conscious manipulation of alignment and opposition of the two arts. (p. 199)

Marisi (2014) acknowledges the benefits of a successful collaboration in that the audience will experience a deep cognitive and emotional involvement (p. 32). Hagen \& Bryrant (2003) point out that complex music and dance performances can only be created by coalitions with considerable internal stability, yet these performances can be displayed and "decoded" in a very short period of time, which may be a contributing factor in the lack of research into collaborative methods (p. 30).

Perhaps this lack of relevant research into the intuitive collaborative processes which take place between artists is why performance theorist Susan Melrose (2009) believes that "dance experts tend, quite reasonably, to ignore academics." 
Melrose expands on this and suggests that academic discourse often analyzes performance as an object, and in doing so ignores the intentions and experiences of the artists themselves (p. 31).

Melrose (2009) highlights how different an expert spectator's view of a performance is to that of a trained dancer or experienced choreographer and recognizes that "expert collaborations, common to much making in the performing arts, are largely mysterious to outsiders" (p. 29). In this chapter Melrose addresses collaboration in terms of the choreographer, allowing practitioners from other disciplines a small amount of creative freedom whilst creating something which is the empirical fit of the choreographer's ideals (pp. 33-34); whilst she acknowledges that the chapter is written in terms of dance, this is arguably a limited view of the spectrum of possibilities within artistic collaboration.

This research is important as it addresses the potential methods and relationships available to choreographers and composers in choreomusical collaboration; previous studies similar to this are limited as they only consider the preferences of the choreographers (McCombe, 1994; Wilden, 2012). For both creators of a choreomusical work, a collaborative creative process must be worthwhile, enjoyable, or contribute something unique to motivate artists to collaborate at a time where, to some degree, technology negates the necessity to do so. Therefore, the scholar interested in choreomusical relationships should also be interested in collaborative creative methods.

\section{Contributions of Technology}

Rapid technological progress has continued to advance choreomusical options dramatically. Guedes (2003) developed and demonstrated an expert system that allows dancers to slightly control the tempo of pre-recorded music in order to encourage interactive performance. Sicchio (2014) explored the option of a dance and live-coding system and suggested that "live-coding emerges as a transdisciplinary approach to live performance. It may be used within live choreographic events to create compositions in real time" (p. 39). Working methods and material exchanges are also becoming effortless; a 2014 paper discussing how cloud-based file sharing and different digital representations of music can facilitate collaborative engagement of musicians concluded that "new opportunities result from the digital medium's capacity to handle digitized forms of music that may now span geographic boundaries and foster connectivity amongst the parties engaged" (Vlachakis, Kalaentzis \& Akoumianakis, 2014, p. 6).

Choreographers utilizing these inevitable developments to create their own accompaniments could leave interdisciplinary collaboration redundant unless the choreographer feels they benefit via the process. John Cage (1968) recognized the simultaneous composition of dance and music as a "great advantage to the modern dance," 
however he commented that choreographers' "use of percussion, unfortunately, has not been constructive" due to the creators having "not given the sound its own and special part in the whole composition" (p. 88). This observation is relevant as it will become more accessible for choreographers to create their own music; however, without musical skill Cage's generalization could become the most common form of music in modern dance. Allen Fogelsanger (1998) does have a more positive prediction for this and suggests that "in the future, instead of dancers moving to an extraneous sound source, they may be the sound source, and a wonderfully rich one at that" (p. 8).

\section{Methodology}

This project has taken two methodological approaches: historical research into twentieth and twenty-first century practices, and sociological and reflexive research into contemporary practices using a grounded theory approach of qualitative research. Firstly, a historical analysis of the potential approaches to collaborative relationships recognizes the cultural specificity of twentieth-century European American post-modern dance practices as creating a distinct genre of work, which has destabilized traditionally intertwined cultural practices of music and dance. This dissertation chooses to focus exclusively on this distinct genre of work and the developments which preceded it; the intention of the spectrum model is to identify the processes currently available in this genre only. Secondly, a discussion of practical knowledge of collaboration articulated by the artists themselves highlights the value of expert practitioner perspectives within the study.

Data was collected through interviews with choreographers and composers, and journals documenting my personal collaborative processes. Due to the relative lack of material reviewed detailing the experiences of choreographers and composers during collaboration, and in light of Melrose's (2009) claim that expert-intuitive practitioner knowledge is often overlooked in arts research (p. 31), it was seen pertinent to use the interviews to focus explicitly on the individual perspectives and concerns of both parties within a collaboration.

This data has then been reviewed, coded, and grouped in order to develop an integrated diagram: a spectrum model of collaborative relationships, which identifies core theoretical concepts determining the degrees of co-creation and satisfaction of both choreographer and composer. This model ${ }^{1}$ is based on Jo Butterworth's spectrum model found in "A Framework for Dance Making and Devising" (2009, pp. 187-188).

\footnotetext{
${ }^{1}$ See Table, p. 188-189: "Spectrum model of the creative processes available to choreographer and composer, and specific requirements of each method."
} 


\section{Discussion}

\section{Hierarchal Trends}

When asked to define co-creation, the necessity of an equal input was ubiquitous amongst choreographers' answers, however it seems some prefer to direct projects in a similar way to that of devised theatre and this is still deemed co-creation despite the clear existence of a hierarchy; methods such as this are documented in Oddey's Devising Theatre (1994) and Lou Cope's research into directing group collaborative work (2016). The composer's definitions were more diverse and for them, as long as a piece is created together, equal input is not a requirement for co-creation; since this trend was amongst all of the composers, it suggests that they do in fact have a more negative or indifferent attitude toward achieving an equal input in a collaboration. It is worth noting that authority is not evenly distributed throughout these standard methods; generally, choreographers have the role of director.

One possible reason for this, highlighted in the interviews, is that choreographers tend to learn the fundamental language of other disciplines more than any other collaborating artist. Therefore, they are able to listen, understand and direct multidisciplinary projects with more sensitivity than other artists may be qualified to do.

\section{Education}

Generally, answers from artists who discussed standard methods of young collaborators were varied, but one common, critical point was the lack of imagination shown by young choreographers' choice of non-commissioned music. This same lack of imagination was not identified in composers; however, music is often presented as a lone discipline. Disregarding site-specific pieces, composers in education are not often required to provide a potential setting for the work they submit, whereas choreographers are expected to present ideas about light, costume and sound. I therefore propose that young composers would generally only work with movement in a collaborative environment. Education in music for contemporary dance is not ubiquitous and education of contemporary dance for composers is scarce, so ill-informed choices and bland tastes in the other art form are common. Modules on choreomusical collaboration are not ubiquitous; those which exist may be short and unclear about different collaborative options, leaving students unaware about the breadth of collaborative opportunities available to them.

It is notable that traditional methods, education and training of choreography and composition are fundamentally different; this may be a contributing factor in any potential dissonance between choreographer and composer. Instructional texts in dance-making recognize collaboration as an important part of the creative process: Butterworth's Dance Studies: The Basics (2012) advises that decisions about potential 
collaborations should be made at the concept stage of the creative process which inevitably maximizes co-creative potential (p. 37). Anna Pakes (2009) recognizes the expectation that choreographers create considering the interdisciplinary:

Choreography in itself is arguably a form of praxis because it involves collective production... Decisions are not generally made according to a technically rational view of how to manipulate the relationships central to dance-making, but rather arise out of the circumstances of the moment and are governed by a different kind of rationality sensitive to contingencies and to the evolving nature of [collaborative] relationships. (pp. 19-20)

In contrast to this, music composition is traditionally solitary; film composer Carter Burwell (2003) admits that he has no interest in speaking to anyone other than the director about his music, claiming it will be of no help to his creative process (p. 198). The traditional methods of both music and dance making have been challenged throughout the development of both popular and experimental music and dance, hence a plethora of working methods are currently available to composers and chorographers; it is arguable that these traditional assumptions are no longer relevant. However, music education often focuses on traditional methods and presentation of work, as composition students are expected to create scores which adhere to instrumental standards with sufficient detail to eliminate need for discussion with the performer(s), or provide tracks of pre-recorded electronic music. Instructional texts such as Paul Hoffert's Music for New Media (2007) even encourage composers to create music systematically as a background for media, allowing little creative input and dismissing collaborative opportunities and the integrity of the composer.

In terms of professional artists training in and understanding of the other art form, it seems language is a universal problem within interdisciplinary work, and one that each collaborative method has to negotiate. Most choreographers and composers acknowledged that some training in the language of other disciplines, in addition to knowledge of the modern developments of the discipline, could be useful. Interestingly, many artists pointed out that training beyond this could impede approaching their collaborator's work with an open mind, and did not express desire to have any further training in the other discipline.

The perspective of a collaborator from another discipline was often highlighted as a valuable tool by both choreographers and composers; this is a distinct contribution of interdisciplinary collaboration. An interdisciplinary perspective then emerges as an important feature of this framework of creativity: "one of the key limitations of systemic models is represented by their institutional perspective on who can legitimate creativity within a society and how creations contribute to a cultural domain" (Glăveanu, 2014, p. 25). 


\section{Social Factors}

In terms of the social dynamic of collaboration, respect and trust of the collaborating artist/s and their work is essentially a ubiquitous requirement amongst identified processes. Assertiveness is a requirement for every method aside from the nondominant roles in Processes One and Seven. This issue can be further complicated by discrimination against minorities, for example: gender discrimination, or professional status. Mapping artists' personal details, locations and considering their culture, religion and traditions of the location of each artist is also necessary to ascertain the effect of this within collaborative relationships and the working methods available to each individual artist.

For example, it is worth noting that of the four Maltese composers interviewed, a trend of composer dominance was identified. The one Maltese composer who does not work in Process One is generally not authoritative in collaborative relationships and was the only composer to work in Process Six, as well as the only female Maltese composer interviewed. A wider selection of artists would need to be interviewed to ascertain the role gender might play in such perceptions, however it is worth acknowledging the significant presence of Catholicism in Malta, and its influence on power relationships within society.

The artists that were more concerned about the quality of a collaborator's work as opposed to their personal attributes and social skills were generally the authoritative figure in the commission based working processes. Artists often noted a preference to work with the same artist on several projects and develop this relationship. In contradiction, one choreographer pointed out a good collaborative relationship is not essential in every process as she sees "many collaborators work together who can't stand each other outside the studio" (Calleja, personal communication, 2016); thus, one can assume that if they fall within the commission based processes, uncomfortable collaborative relationships can be amicable.

Glăveanu (2014) argues that creativity "emerges as an encounter between person and world, a form of distributed activity that acts precisely on the differences above in ways that acknowledge them, exploit their potential, or try to reduce or bridge them" (p. 27). Regardless of the perceived success of the relationship, the development of and direction of this collaborative process through time is arguably always a contributing factor in the outcome of any process, and the relationship of that outcome with its audience and/or surroundings.

\section{Conclusions}

This spectrum could serve as a tool for students to illustrate the possible options and requirements of each party in order to develop clearer and more satisfying collaborative projects. Butterworth's spectrum model, the basis of the model presented in 
this dissertation, was developed specifically for teaching dance in higher education, so the potential applications of my spectrum model to pedagogy are significant.

It is important to note that time, funding and other practical considerations are contributing factors of working processes in any given project. Regardless of these factors, this paper has identified that this is an interesting avenue of research with many potentially useful explorations and highlighted that interdisciplinary collaboration does contribute something distinct in a creative working process. I hope that more scholars and artists take an active interest in choreomusical collaboration in the future and further explore the working processes available in order to develop interesting collaborative relationships and choreomusical works.

Collaborative relationships are important throughout the arts and beyond, and all of these processes are worthy and interesting areas of research; future comparison of any similar collaborative research in different disciplines could lead to insightful discovery.

As composer James Wyness (personal communication, 2016) pointed out when discussing this research, "[t]he larger part of the pleasure from working in this field is derived from the process, the journey over the destination or means over ends."

\section{References}

Burwell, C. (2003). Composing for the Coen Brothers. In L. Sider, D. Freeman, \& J. Sider (Eds.), Soundscape: The school of sound lectures 1998-2001 (pp. 195-208). London, UK: Wallflower Press.

Butterworth, J. (2009). Too many cooks? A framework for dance making and devising. In J. Butterworth \& L. Wildschut (Eds.), Contemporary choreography: A critical reader (pp. 177-194). London, UK: Routledge.

Butterworth, J. (2012). Dance studies: The basics. London, UK: Routledge.

Cage, J. (1968). Silence: Lectures and writings. London, UK: Calder and Boyars.

Cope, L. (2016). PhD Information. Retrieved November 8, 2017 from https://web.archive.org/web/20160530000743/http://loucope.com/research/phd-info/

Fogelsanger, A. (1998, August). Music composition for dance in the twenty-first century: Questions about the dance/music relationship. Paper presented at the $3^{\text {rd }}$ European Conference of the International Guild of Musicians in Dance Conference, Stockholm, Sweden.

Glăveanu, V. P. (2014). Distributed creativity: Thinking outside the box of the creative individual. Cham, Switzerland: Springer. doi:10.1007/978-3-319-05434-6

Guedes, C. (2003). Controlling musical tempo from dance movement in real-time: A possible approach. International Computer Music Conference, 2003, 453-457. Retrieved from http://hdl.handle.net/2027/spo.bbp2372.2003.094

Hagen, E. H., \& Bryant, G. A. (2003). Music and dance as a collation signalling system. Human Nature. 14(1), 21-51. doi:10.1007/s12110-003-1015-z 
Hodgins, P. (1992). Relationships between score and choreography in twentieth-century dance music, movement, and metaphor. New York, NY: Edwin Mellen Press.

Hoffert, P. (2007), Music for new media: Composing for videogames, web sites, presentations, and other interactive media. J. Feist (Ed.). Boston, MA: Berklee Press.

Marisi, R. (2014). Music and dance as a whole. Review of Artistic Education, 7-8, 26-33.

McCombe, C, A. (1994). Slave to the dance? The role and function of music in the work of four contemporary Australian choreographers (Doctoral dissertation). University of Melbourne, Melbourne, Australia.

McMains J., \& Thomas B. (2013). Translating from pitch to plié: Music theory for dance scholars and close movement analysis for music scholars. Dance Chronicle, 36(2), 196-217. doi:10.1080/01472526.2013.792714

Melrose, S. (2009). Expert-intuitive processing and the logics of production: struggles in (the wording of) creative decision-making in dance. In J. Butterworth \& L. Wildschut (Eds.), Contemporary choreography: A critical reader (pp. 23-37). London, UK: Routledge.

Oddey, A. (1994). Devising theatre: A practical and theoretical handbook. London, UK: Routledge.

Pakes, A. (2009). Knowing through dance-making: Choreography, practical knowledge and practice-as-research. In J. Butterworth \& L. Wildschut (Eds.), Contemporary choreography: A critical reader (pp. 10-22). London, UK: Routledge.

Sicchio, K. (2014). Hacking choreography: Dance and live coding. Computer Music Journal, 38(1), 31-39. doi:10.1162/COMJ_a_00218

Vlachakis, G., Kalaentzis, A., \& Akoumianakis, D. (2014). Collaborative music composition as virtual work across boundaries. In 2014 International Conference on Telecommunications and Multimedia (TEMU) (pp. 202-207). doi:10.1109/TEMU.2014.6917761

Wilden, S. (2012). From ear to foot: How intuitive choreographers interpret music (Master thesis). University of New Mexico, Albuquerque, NM. Retrieved from http://digitalrepository.unm.edu/cgi/viewcontent.cgi?article=1002\&context=mus_etds 


\section{Appendix}

Table. Spectrum model of the creative processes available to choreographer and composer, and specific requirements of each method.

\begin{tabular}{|c|c|c|c|c|c|c|c|}
\hline Process & Process 1 & Process 2 & Process 3 & Process 4 & Process 5 & Process 6 & Process 7 \\
\hline Hierarchy & $\begin{array}{l}\text { Composer in } \\
\text { control. }\end{array}$ & $\begin{array}{l}\text { Composer in } \\
\text { control but open } \\
\text { to discussion. }\end{array}$ & $\begin{array}{l}\text { Open collaboration } \\
\text { with composer as } \\
\text { director. }\end{array}$ & No hierarchy. & $\begin{array}{l}\text { Open collaboration } \\
\text { with choreographer } \\
\text { as director. }\end{array}$ & $\begin{array}{l}\text { Choreographer } \\
\text { in control but } \\
\text { open to discus- } \\
\text { sion. }\end{array}$ & $\begin{array}{l}\text { Choreographer } \\
\text { in control. }\end{array}$ \\
\hline $\begin{array}{l}\text { Emergence of } \\
\text { concept }\end{array}$ & $\begin{array}{l}\text { Composer's } \\
\text { concept is } \\
\text { realised by } \\
\text { choreogra- } \\
\text { pher. }\end{array}$ & $\begin{array}{l}\text { Composer's con- } \\
\text { cept is inter- } \\
\text { preted by } \\
\text { choreographer. }\end{array}$ & $\begin{array}{l}\text { Composer's con- } \\
\text { cept is discussed } \\
\text { and developed } \\
\text { with choreogra- } \\
\text { pher. }\end{array}$ & $\begin{array}{l}\text { Concept emerges } \\
\text { via both artists OR } \\
\text { interests both art- } \\
\text { ists and is created, } \\
\text { explored and de- } \\
\text { veloped together. }\end{array}$ & $\begin{array}{l}\text { Choreographer's } \\
\text { concept is discussed } \\
\text { and developed with } \\
\text { composer. }\end{array}$ & $\begin{array}{l}\text { Choreographer's } \\
\text { concept is inter- } \\
\text { preted by com- } \\
\text { poser. }\end{array}$ & $\begin{array}{l}\text { Choreographer's } \\
\text { concept is real- } \\
\text { ised by com- } \\
\text { poser. }\end{array}$ \\
\hline $\begin{array}{l}\text { Requirements } \\
\text { of composer }\end{array}$ & $\begin{array}{l}\text { Generation } \\
\text { of concept, } \\
\text { structure, } \\
\text { style and } \\
\text { musical ma- } \\
\text { terial. }\end{array}$ & $\begin{array}{l}\text { Generation of } \\
\text { concept, struc- } \\
\text { ture, style and } \\
\text { musical mate- } \\
\text { rial in relation } \\
\text { to capabilities/ } \\
\text { style of the cho- } \\
\text { reographer. }\end{array}$ & $\begin{array}{l}\text { Generation of con- } \\
\text { cept/contribution } \\
\text { toward generation } \\
\text { of concept. } \\
\text { Contribution to- } \\
\text { ward exploring/ } \\
\text { discovering struc- } \\
\text { ture, style, etc. } \\
\text { Direction of project } \\
\text { where necessary. } \\
\text { Understanding of } \\
\text { all other art forms } \\
\text { involved in project. } \\
\text { Generation of mu- } \\
\text { sical material. } \\
\text { Time. }\end{array}$ & $\begin{array}{l}\text { Contribute ideas } \\
\text { and facilitate the } \\
\text { shared explora- } \\
\text { tion and discovery } \\
\text { of the concept, } \\
\text { structure and } \\
\text { style of the piece. } \\
\text { Generation of mu- } \\
\text { sical material, } \\
\text { time. }\end{array}$ & $\begin{array}{l}\text { Contribution toward } \\
\text { exploring/ discover- } \\
\text { ing concept, style, } \\
\text { structure, etc. } \\
\text { Generation of musi- } \\
\text { cal material, time. }\end{array}$ & $\begin{array}{l}\text { Sensitivity to } \\
\text { movement. } \\
\text { Generate an au- } \\
\text { dible interpreta- } \\
\text { tion of the } \\
\text { choreographer's } \\
\text { ideas. }\end{array}$ & $\begin{array}{l}\text { Sensitivity to } \\
\text { movement. } \\
\text { Generate an au- } \\
\text { dible realisation } \\
\text { of the choreog- } \\
\text { rapher's ideas. }\end{array}$ \\
\hline
\end{tabular}




\begin{tabular}{|c|c|c|c|c|c|c|c|}
\hline Process & Process 1 & Process 2 & Process 3 & Process 4 & Process 5 & Process 6 & Process 7 \\
\hline $\begin{array}{l}\text { Requirements } \\
\text { of choreogra- } \\
\text { pher }\end{array}$ & $\begin{array}{l}\text { Musicality. } \\
\text { Generate a } \\
\text { visual reali- } \\
\text { sation of the } \\
\text { composer's } \\
\text { ideas. }\end{array}$ & $\begin{array}{l}\text { Musicality. } \\
\text { Generate a vis- } \\
\text { ual interpreta- } \\
\text { tion of the } \\
\text { composer's } \\
\text { ideas. }\end{array}$ & $\begin{array}{l}\text { Contribution to- } \\
\text { ward explor- } \\
\text { ing/discovering } \\
\text { concept, style, } \\
\text { structure, etc. } \\
\text { Generation of } \\
\text { movement mate- } \\
\text { rial. } \\
\text { Time. }\end{array}$ & $\begin{array}{l}\text { Contribute ideas } \\
\text { and facilitate the } \\
\text { shared explora- } \\
\text { tion and discovery } \\
\text { of the concept, } \\
\text { structure and } \\
\text { style of the piece. } \\
\text { Generation of } \\
\text { movement mate- } \\
\text { rial. } \\
\text { Time. }\end{array}$ & $\begin{array}{l}\text { Generation of con- } \\
\text { cept/contribution } \\
\text { toward generation } \\
\text { of concept. } \\
\text { Contribution toward } \\
\text { exploring/discover- } \\
\text { ing structure, style, } \\
\text { etc. } \\
\text { Direction of project } \\
\text { where necessary. } \\
\text { Understanding of all } \\
\text { other art forms in- } \\
\text { volved in project. } \\
\text { Generation of move- } \\
\text { ment material. } \\
\text { Time. }\end{array}$ & $\begin{array}{l}\text { Generation of } \\
\text { concept, struc- } \\
\text { ture, style and } \\
\text { musical material } \\
\text { in relation to ca- } \\
\text { pabilities/style } \\
\text { of the composer. }\end{array}$ & $\begin{array}{l}\text { Generation of } \\
\text { concept, struc- } \\
\text { ture, style and } \\
\text { movement ma- } \\
\text { terial. }\end{array}$ \\
\hline $\begin{array}{l}\text { Social } \\
\text { requirements of } \\
\text { composer }\end{array}$ & $\begin{array}{l}\text { Confidence, } \\
\text { devotion. }\end{array}$ & $\begin{array}{l}\text { Confidence, } \\
\text { communication, } \\
\text { listening, devo- } \\
\text { tion. }\end{array}$ & $\begin{array}{l}\text { Confidence, com- } \\
\text { munication, listen- } \\
\text { ing, openness, } \\
\text { devotion, willing- } \\
\text { ness to take risks. }\end{array}$ & $\begin{array}{l}\text { Confidence, com- } \\
\text { munication, lis- } \\
\text { tening, openness, } \\
\text { fluidity, devotion, } \\
\text { ability to let ideas } \\
\text { go willingness to } \\
\text { take risks. }\end{array}$ & $\begin{array}{l}\text { Confidence, commu- } \\
\text { nication, listening, } \\
\text { compromising, will- } \\
\text { ingness to take } \\
\text { risks, devotion, } \\
\text { openness, ability to } \\
\text { let ideas go. }\end{array}$ & $\begin{array}{l}\text { Malleability, al- } \\
\text { truism, commu- } \\
\text { nication, } \\
\text { listening. }\end{array}$ & $\begin{array}{l}\text { Malleability, al- } \\
\text { truism, listening. }\end{array}$ \\
\hline $\begin{array}{l}\text { Social } \\
\text { requirements of } \\
\text { choreographer }\end{array}$ & $\begin{array}{l}\text { Malleability, } \\
\text { altruism, lis- } \\
\text { tening. }\end{array}$ & $\begin{array}{l}\text { Malleability, al- } \\
\text { truism, commu- } \\
\text { nication, } \\
\text { listening. }\end{array}$ & $\begin{array}{l}\text { Confidence, com- } \\
\text { munication, listen- } \\
\text { ing, compromising, } \\
\text { willingness to take } \\
\text { risks, devotion, } \\
\text { openness, ability to } \\
\text { let ideas go. }\end{array}$ & $\begin{array}{l}\text { Confidence, com- } \\
\text { munication, lis- } \\
\text { tening, openness, } \\
\text { fluidity, devotion, } \\
\text { ability to let ideas } \\
\text { go, willingness to } \\
\text { take risks. }\end{array}$ & $\begin{array}{l}\text { Confidence, commu- } \\
\text { nication, listening, } \\
\text { openness, devotion, } \\
\text { willingness to take } \\
\text { risks. }\end{array}$ & $\begin{array}{l}\text { Confidence, } \\
\text { communication, } \\
\text { listening, devo- } \\
\text { tion. }\end{array}$ & $\begin{array}{l}\text { Confidence, de- } \\
\text { votion. }\end{array}$ \\
\hline
\end{tabular}




\section{First response to "An Argument for Investigation into Collaborative, Choreo- musical Relationships within Contemporary Performance: A Practical and The- oretical Enquiry into the Distinct Contributions of a Collaborative, Co-creative Approach" by Joanne “Bob” Whalley}

This is a rich seam for discussion, and one which has a deep historical grounding. There is constant curiosity around how the collaborations of John Cage and Merce Cunningham, Igor Stravinsky and George Balanchine, Louis Horst and Martha Graham, for example, were created and maintained. I am interested in the methodology for an investigation into the distinctions between co-authorship and collaboration within choreomusicology. What might be differences, shifts, overlappings, developments, between being both within and without the choreomusical process: are knowledges different for the creators and commentators of the work (and these might also be in the same bodies, so "doing things" differently at different times)?

Concerning the philosophy of collaboration, or collective creation, with its "nonhierarchical, egalitarian nature" (Cull, 2013, p. 45), certainly Deleuze and Guattari can be useful here around questions of authorship, indeed "body without organs," "becoming," "rhizome" and "affect" feature as prominent terms for contemporary dance practitioners. The project appears to seek beyond a democratization of interpretation, and Deleuze and Guattari find means by which ownership is genuinely shared. Critical arguments around authorship and shared knowledge production can be found in Colin and Sachsenmaier's recent book Collaboration in Performance Practice: Premises, Workings and Failures. In it Laura Cull Ó Maoilearca states: "[e]ven the most apparently individual or solo practice might in fact contain strong collaborative elements. The creator of a performance may not acknowledge the collaboration of the audience, but this does not prevent that collaboration from happening. And likewise, a project calling itself 'a collaboration' may nevertheless express individualistic tendencies" (Cull, 2016, p. 97).

Founding member of Goat Island performance group Matthew Goulish values collaboration because it offers the chance to "[e]scape from ourselves, from the limited perspective of the individual ego ... Who we were, when we met, how we proceeded, what we produced, all seem products of the togetherness, the conjunction ... Escaping our individual limitations was certainly one of our goals-and not only limitations of identity, but also of thought, imagination, history and progress" (Goulish, 2000, p. 15).

Claire Bishop states that "[a]rtists are increasingly judged by their working process-the degree to which they supply good or bad models of collaboration-and criticized for any hint of potential exploitation that fails to 'fully' represent their subjects, as if such a thing were possible" (Bishop, 2006, p. 180). The work of choreographer and composer Jonathan Burrows and Matteo Fargion could be of importance 
as current practitioners tussling choreomusically. Sections from some of their collaborations: Both Sitting Duet (2002), Quiet Dance (2005), Speaking Dance (2006), Cheap Lecture (2006), The Cow Piece (2009), Counting to one hundred (2011), One Flute Note (2012), Body Not Fit for Purpose (2014), can be found at: http://scores.motionbank.org/jbmf/\#/set/all-duets. Fargion and Burrows both use scores, separately and together, that kind of notational system that secures against its own disappearance. Of his scores, Fargion says: "At first only way I could think of it was treating it like music, tricking myself into thinking I was playing a percussion piece, which is a trick I sometimes still use. Depending on the performance, the accuracy of the movements comes very much from the musicality: the score is written musically and I am just performing that. The fact that it is bigger movement and does not actually produce sound is immaterial" (Burrows \& Fargion, 2008).

And I think Cull finishes best on the thoughts of collaboration:

Performance thinks in its own, multiple ways: as the emergent, decentralized thinking of collaboration and collective creation, which challenges our habitual, proprietorial thought; as the stammerings, stutterings and whisperings that assure an identity of self and voice as much as they speak difference and vibrate those who hear them; as mutually empowering encounters between the human and the nonhuman, where immanent imitations tend towards one body's continuation of another's movement; as events of experienced insight and attentive respect that increase our participation in an always unfinished, incomplete whole; as an extended 'open-ness' to other durations, to the impatience of waiting sometimes, to the exhaustion of accelerations at other times. Open the window a little wider... Open to others ... For goodness is itself a matter of movement and composition; a part, relative, open. (Cull, 2013, p. 240)

\section{References}

Bishop, C. (2006). The social turn: Collaboration and its discontents, Artforum, 44, 179-185.

Burrows, J., \& Fargion, M. (2008). The musical body: Guy Cools with Jonathan Burrows and Matteo Fargion: Sadlers's Wells Theatre, 2008 (G. Cools, Interviewer), Official website of choreographer Jonathan Burrows. Retrieved from http://www.jonathanburrows.info/\#/text/?id=58\&t=content

Cull, L. (2013). Theatres of immanence: Deleuze and the ethics of performance. London, UK: Palgrave.

Cull, L. (2016). Since each of us was several: Collaboration in the context of the differential self. In N. Coiln \& S. Sachsenmaier (Eds.), Collaboration in performance practice: Premises, workings and failures (pp. 93-107). Basingstoke, UK: Palgrave Macmillan. doi:10.1057/9781137462466_5

Deleuze, G., \& Guattari, F. (2004). A thousand plateaus, capitalism and schizophrenia. (B. Massumi, Trans.), London, UK: Continuum. (Original work published 1980)

Goulish, M. (2000). 39 microlectures: In proximity of performance. London, UK: Routledge. 


\section{Other research that might be of interest}

Blades, H. (2016). Work(s) and (non)production in contemporary movement practices. Performance Philosophy, 2(1), 35-54. doi:10.21476/PP.2016.21105

Jordan, S. (2010). Ravel dances: 'choreomusical' discoveries in Richard Alston's Shimmer. In D. Mawer (Ed.), Ravel studies (pp. 165-186). Cambridge, UK, Cambridge University Press.

Jordan, S. (2011). Choreomusical conversations: Facing a double challenge. Dance Research Journal, 43(1), 43-64.

Jordan, S. (2015). Mark Morris: Musician-choreographer, Hampshire, UK: Dance Books.

Nelson, R. (2006). Practice-as-research and the problem of knowledge. Performance Research, 11(4), 105-116. doi:10.1080/13528160701363556 
Second response to "An Argument for Investigation into Collaborative, Choreomusical Relationships Within Contemporary Performance: A Practical and Theoretical Enquiry into the Distinct Contributions of a Collaborative, Cocreative Approach" by Michael Straeubig

The article discusses aspects of collaboration between co-creators. In particular, it is about choreographers and composers who create common works that involve both music and dance. It draws a distinction between the outcome of a creative endeavor and the satisfaction of the participants.

In this response I want to look at the article from three general perspectives.

The first approach is to apply its themes to other creative processes in which practitioners of different media take part to form a common result. An example would be game design (Schell, 2015). Like choreomusical works, games usually include multiple media like audio, visuals or interactive interfaces. Different forms appear in these media, such as rules or narration. Investigating the relationship between these media and between medium and form (Luhmann, 1997, pp. 165-214) in this context seems a promising avenue.

A second general approach would be to observe the interactions during creative collaboration as social systems-systems that operate with communication. This also opens up investigations into sense-making as communicative acts involve expectations, (mis)understandings, meta-communication. "One cannot not communicate" (Watzlawick, Beavin, \& Jackson, 2007). Coupled to those acts are feelings and emotions (Rouhiainen \& Hämäläinen, 2013).

The third perspective, which is connected to the second one, is about the concept of relationships and power. It is reflected in the article in the form of a categorization based on Butterworth (2009). For me it remains unclear if idealized categories such as "Composer in control" versus "Composer in control but open to discussion" correspond to the reality of a working relationship. Maybe there are descriptions that could mirror more closely the shifting intricacies and dynamics of individual power relations? One such perspective might be resistance, for example (Foucault, 1982).

Finally, it would be interesting to discuss all three perspectives in the context of technology. 


\section{References}

Butterworth, J. (2009). Too many cooks? A framework for dance making and devising. In J. Butterworth \& L. Wildschut (Eds.), Contemporary choreography: A critical reader (pp. 177-194). London, UK: Routledge.

Foucault, M. (1982). The subject and power. Critical Inquiry, 8(4), 777-795. doi:10.1086/448181

Luhmann, N. (1997). Die Kunst der Gesellschaft. Frankfurt am Main, Germany: Suhrkamp.

Rouhiainen, L., \& Hämäläinen, S. (2013). Emotions and feelings in a collaborative dancemaking process. International Journal of Education \& the Arts, 14(6). Retrieved from http://www.ijea.org/v14n6/

Schell, J. (2015). The art of game design: A book of lenses (2nd ed.). Boca Raton, FL: CRC Press.

Watzlawick, P., Beavin, J. H., \& Jackson, D. D. (2007). Some tentative axioms of communication. In R. T. Craig \& H. L. Muller (Eds.) Theorizing communication: Readings across traditions (pp. 275-288). Los Angeles, CA: Sage Publications. 